\title{
Action of Different Proteolytic Enzymes on the Surface of Nucleated Red Cells
}

\author{
By G. Wintzer and G. UhLENBRuck \\ Cbirurgische Universitätsklinik (Direktor: Prof. Dr. G. Heberer) und Medizinische Universitätsklinik
}

(Direktor: Prof. Dr. R. Gross) Köln-Lindentbal

(Eingegangen am 10. Februar 1971)

The action of several proteolytic enzymes on the surface of nucleated red cells (chicken) was investigated by isoelectric focusing of the released mucopeptides. It was found, that each protease splits off a characteristic mucopeptide pattern. In addition to these glycoproteinderived substances, a phosphorus-containing fraction was also liberated. Similar observations were made with duck erythrocytes.

Die Wirkungsweise verschiedener proteolytischer Enzyme auf die Oberfläche kernhaltiger Erythrocyten (Huhn) wurde mit Hilfe der Isoelektrischen Fokussierung untersucht. Es zeigte sich, daß jede Protease ein charakteristisches Mucopeptidspektrum abtrennt. Außer diesem Glykoproteinmaterial wurde auch noch eine phosphorhaltige Fraktion abgelöst. Ähnliche Beobachtungen wurden bei Entenblutkörperchen gemacht.

In previous papers we have investigated the heterogeneity of genuine erythrocyte mucoids from several sources by using the isoelectric focusing fractionation procedure $(1,2)$. In the course of these investigations we also included experiments dealing with the mucopeptide fractions, released by the action of one proteolytic enzyme, pronase, on different red cells. The aim of this report is to demonstrate the heterogeneity of mucopeptides removed from the red cells of one species by different proteases. For this purpose we chose chicken erythrocytes, as we have already shown that mucopeptides derived from nucleated red cells have some remarkable and interesting biochemical properties (2), which will be further discussed in the present work.

\section{Material and Methods \\ Materials}

Blood: Blood was collected in $3.8 \%$ citrate solution at a chicken farm during slaughtering. The pooled blood was used on the same day for the experiments.

Enz'mes: Papain (EC 3.4.4.10), cryst., pure (ca. 12 EU/mg) Serva, Heidelberg.

Trypsin (EC 3.4.4.4), $2 \times$ cryst. lyophil., pure, salt-free (180 EU/ mg) Serva, Heidelberg

Pilz-Proteinase $\mathrm{K}$ of fungal origin has recently described by us in detail (3), it comes from Tritirachium album LrMBER and is commercially available from Merck, Darmstadt.

Subtilisin Type Carlsberg (Subtilopeptidase A (EC 3.4.4.16)) (32.0 Anson units/g), Batch 90919, Novo Industri, Oslo, Norway. Pronase B grade (Lot 000333) Calbiochem., Los Angeles, USA.

$\alpha$-Chymotrypsin (Chymotrypsin A (EC 3.4.4.5)), salt-free, $3 \times$ cryst. puriss. Carl Roth, Karlstuhe.

Preparative Methods

Enz'me treatment: The washed red cells were treated with a $0.01 \%$ enzyme solution in $0.066 \mathrm{M} \mathrm{Na} \mathrm{HPO}_{4} / \mathrm{KH}_{2} \mathrm{PO}_{4}$ buffer according to SöRENSEN, and $0.325 \mathrm{M} \mathrm{NaCl}, \mathrm{pH} 7,0$ as described previously (1).

Isolation of mucopeptides: Erythrocyte mucopeptides were prepared by cold phenol/saline $(\nabla / v)$ extraction of the supernatant of the incubation mixture after enzyme treatment (4). The filtered and centrifuged water layer was dialysed against distilled water and subsequently lyophilized. This substance was then used as starting material for the isoelectric focusing fractionation $(1,2)$.

Isoelectric focusing: The method of isoelectric focusing bas already been described in detail (1). For further details see explanations in Figure 1.

\section{Analytical Methods}

All analytical methods, neuraminic acid estimation with BraLs reagent and protein determination after LowRY, have already been described in our previous paper on this subject $(1,2)$. In addition, phosphorus was estimated according to the method of Torsten TEORELL (5), because phosphorus-containing fractions had been found when analysing the mucopeptides from nucleated red cells, e. g., duck red cells (2).

\section{Results}

The results of our experiments are given in figure 1. This figure demonstrates, that under the same incubation conditions $\left(30 \mathrm{~min}\right.$ at $\left.37^{\circ}\right)$, using an enzyme concentration of $0.01 \%$, not only different amounts of mucopeptides are released from the same volume of packed red cells $(300 \mathrm{ml})$, but also various sorts of different mucopeptides, giving a characteristic pattern, which depends on the enzyme used. This enzymecharacteristic pattern is revealed by the fractionation of the released mucopeptides by isoelectric focusing. This picture can hardly be influenced by individual variation, as we pooled blood from several hundred individual chickens. The heterogeneity of the neuraminic acidcontaining fractions at the beginning of the curve in the acid $\mathrm{pH}$ area should be mentioned. As Table 1 shows, this heterogeneity is due to a different content of neuraminic acid and phosphorus within each fraction, and at each isoelectric point, both of which vary according to the enzyme used for the release of the mucopeptides.

In Table 1 quantitative analytical data of the different fractions from each sample are given. First of all there are obvious differences in the analyses of the material, which has been split off by the different enzymes. This 
holds especially for the neuraminic acid and phosphorus content, where marked differences can be noticed (for instance fungal proteinase and trypsin preparation). The neuraminic acid is usually enriched in the acid fractions with regard to the $\mathrm{pH}$ gradient. This can be observed in all samples, irrespective of the protease used. On the other hand, the phosphorus content, which is not

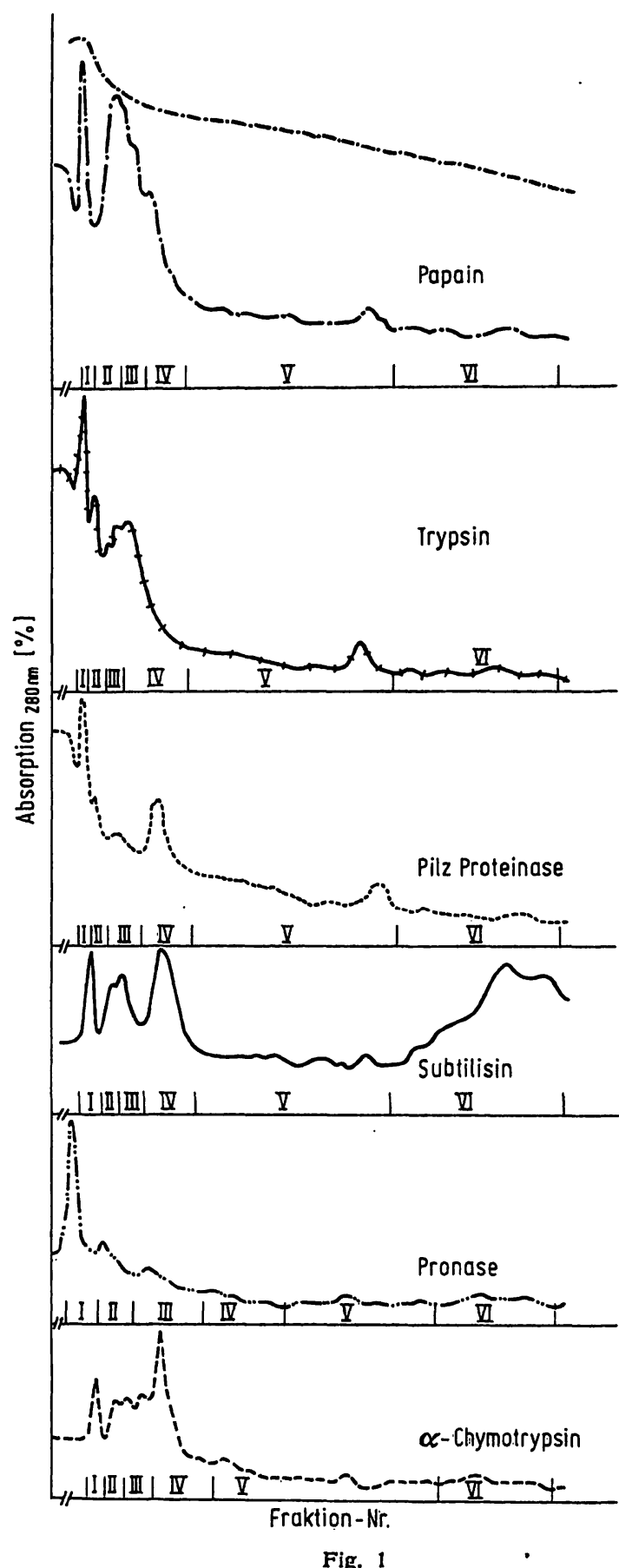

Separation by isoelectric focusing of $50.0 \mathrm{mg}$ mucopeptides from each preparation, which have been removed from nucleated chicken red preparation, which have been removed from nucleated chicken red
cells with a $0.01 \%$ solution of the respective protease. The sepa-
ration was performed in a LKB 8102 column ration was performed in a LKB 8102 column (Ampholine pH 3-6) during 36 hrs at $+4^{\circ}$. Anode resp. anodic solution was at the bottom,
voltage $300 \mathrm{~V}$, current intensity at the beginning 9.5 to $28.0 \mathrm{~mA}$, finally constant at $1.7-3.1 \mathrm{~mA}$. The solid circles represent the $\mathrm{pH}$ gradient measured at $25^{\circ}$; the differently marked curve lines represen the absorbance at $280 \mathrm{~nm}\left(0.1^{\prime} \mathrm{cm}\right.$ cell $)$ read during evacuation of the column, and they are characteristic for the mixture of splitting products from each enzyme. The total amount of mucopeptides released from $300 \mathrm{ml}$ of packed red cells was for the respective enzymes: papain (53.3 $\mathrm{mg}$ ), trypsin $(57.5 \mathrm{mg})$, fungal proteinase $(55.8 \mathrm{mg})$ subtilisin (51.3 $\mathrm{mg}$ ), 'pronase $(57.5 \mathrm{mg})$, a-chymotrypsin $(53.2 \mathrm{mg})$.
Pilz-Proteinase (commercial name) in the picture is identical with fungual proteinase in the text altered by lipid extraction of the fractions, shows a random distribution over all fractions, but there is no enrichment or accumulation of this material by this fractionation procedure. This is explained by the fact, that, when the starting material was brought together with ampholine solution, a certain amount of the phosphorus-containing, gelatinous and viscous substance was precipitated and could not be recovered by resolubilisation in aqueous solutions. The precipitin effect of the ampholine was complete in the last three samples (subtilisin, pronase and $\alpha$-Chymotrypsin) as can be seen in Table 1. The phosphorus content in these materials is relatively high, if one considers, that pure phospholipid preparations usually contain 3.0 to $3.5 \%$ phosphorus. The protein estimation demonstrates, that besides neuraminic acid-containing glycoproteins there are also smaller amounts of neutral glycoproteins or even pure protein material $(1,2)$.

\section{Discussion}

Our results lead to the conclusion, that the different specificity of proteolytic enzymes can also be demonstrated by their action on red cell surfaces. This implicates not only that a comparison between different proteases by this method is possible, but also, that, by using different enzymes, several mucopeptide fractions, which are not completely identical, can be obtained. This provides the possibility of a subsequent protease treatment of the cell surface and of inactivating different antigenic or topographic areas within the surface glycoprotein coat.

The relatively high phosphorus content in these preparations of mucopeptides, which has not been found in preparations from non-nucleated cells, is very interesting. This observation has been confirmed in this and Prof. KLenks laboratory several times, when working with nucleated cells from different sources and was first described in 1962 by SeAman and UhlenBRUCK (6) as a nucleic acid (phosphorus and ribose containing) fraction, released by $\alpha$-chymotrypsin from chicken red cells. We rechecked the phosphorus content of these earlier preparations and found no difference to the preparations made ten years later from other chicken blood red cells. The occurence of nucleic acid material on the surface of nucleated red cells must be considered in the light of the clinical observation that these cells do react with anti-nucleic acid antibodies (so - called Lupus erythematodes serum from patients with certain autoimmune diseases) (7).

On the other hand, the rise in the electrophoretic mobility in chicken and other nucleated red cells after protease treatment (8), a change, which is resistant to neuraminidase treatment, may be due to the appearence of phosphorus-containing groups on the electrokinetic active surface (zetapotential) of these erythrocytes, in spite of the fact, that this material can be partly removed by the action of proteases, as our experiments have proven. The substance is also "visible" as a very gelatinous mass after the enzyme incubation 
Tab. 1

Comparative analytical data of the mucopeptide fractions from nucleated chicken red cells after enzyme-treatment of the intact erythrocytes with different proteases (corresponding to the isoelectric focusing pattern shown in Fig. 1)

\begin{tabular}{|c|c|c|c|c|c|c|c|c|}
\hline & Enzyme & Fraction & $\begin{array}{c}\text { Neuraminic } \\
\text { Acid } \\
\mu \mathrm{g} / 100 \mathrm{ml}\end{array}$ & $\begin{array}{l}\text { Protein } \\
\mathrm{g} / 100 \mathrm{ml}\end{array}$ & $\begin{array}{l}\text { Phosphoru } \\
\mathrm{mg} / 100 \mathrm{~m}\end{array}$ & & & \\
\hline & Papain & $\begin{array}{l}\text { Starting Material } \\
\text { Fraction I } \\
\text { Fraction II } \\
\text { Fraction III } \\
\text { Fraction IV } \\
\text { Fraction V } \\
\text { Fraction VI }\end{array}$ & $\begin{array}{l}13.95 \\
21.88 \\
22.43 \\
11.76 \\
\varnothing \\
\varnothing\end{array}$ & $\begin{array}{l}15.00 \\
21.00 \\
22.00 \\
38.00 \\
56.50 \\
80.00 \\
50.00\end{array}$ & $\begin{array}{r}2.7400 \\
0.1344 \\
0.0840 \\
0.5292 \\
0.5460 \\
0.1260 \\
0.1176\end{array}$ & $\cdot 1$ & & \\
\hline & Trypsin & $\begin{array}{l}\text { Starting Material } \\
\text { Fraction I } \\
\text { Fraction II } \\
\text { Fraction III } \\
\text { Fraction IV } \\
\text { Fraction V } \\
\text { Fraction VI }\end{array}$ & $\begin{array}{l}10.76 \\
\% \% \\
18.42 \\
14.62 \\
13.04 \\
\varnothing \\
\varnothing\end{array}$ & $\begin{array}{l}25.00 \\
\% \% \\
18.75 \\
21.00 \\
18.00 \\
\%\end{array}$ & $\begin{array}{l}3.3180 \\
\% .1 \% \\
0.176 \\
0.3780 \\
\% \\
\%\end{array}$ & & & \\
\hline & Fungal Proteinase & $\begin{array}{l}\text { Starting Material } \\
\text { Fraction I } \\
\text { Fraction II } \\
\text { Fraction III } \\
\text { Fraction IV } \\
\text { Fraction V } \\
\text { Fraction VI }\end{array}$ & $\begin{array}{l}18.30 \\
\varnothing \\
19.39 \\
17.03 \\
\varnothing \\
\varnothing\end{array}$ & $\begin{array}{l}24.50 \\
27.00 \\
23.00 \\
26.00 \\
52.50 \\
53.00 \\
36.00\end{array}$ & $\begin{array}{l}1.0920 \\
0.0252 \\
0.1008 \\
\% . \\
0.0924 \\
\%\end{array}$ & & & \\
\hline & Subtilisin & $\begin{array}{l}\text { Starting Material } \\
\text { Fraction I } \\
\text { Fraction II } \\
\text { Fraction III } \\
\text { Fraction IV } \\
\text { Fraction V } \\
\text { Fraction VI }\end{array}$ & $\begin{array}{l}15.07 \\
14.56 \\
18.39 \\
20.00 \\
14.68 \\
\varnothing\end{array}$ & $\begin{array}{l}19.00 \\
23.50 \\
20.00 \\
21.50 \\
36.00 \\
54.00 \\
63.50\end{array}$ & $\begin{array}{l}1.3356 \\
\varnothing \\
\varnothing \\
\varnothing \\
\varnothing \\
\varnothing \\
\%\end{array}$ & & - & - \\
\hline$:$ i & Pronase & $\begin{array}{l}\text { Starting Material } \\
\text { Fraction I } \\
\text { Fraction II } \\
\text { Fraction III } \\
\text { Fraction IV } \\
\text { Fraction V } \\
\text { Fraction VI }\end{array}$ & $\begin{array}{l}16.78 \\
16.05 \\
18.21 \\
13.52 \\
\varnothing \\
\varnothing\end{array}$ & $\begin{array}{l}17.00 \\
21.00 \\
30.00 \\
67.50 \\
81.50 \\
93.50 \\
50.80\end{array}$ & $\begin{array}{l}0.4116 \\
\varnothing \\
\varnothing \\
\varnothing \\
\varnothing\end{array}$ & & & \\
\hline & $\alpha$-Chymotrypsin & $\begin{array}{l}\text { Starting Material } \\
\text { Fraction I } \\
\text { Fraction II } \\
\text { Fraction III } \\
\text { Fraction IV } \\
\text { Fraction V } \\
\text { Fraction VI }\end{array}$ & $\begin{array}{l}10.19 \\
\varnothing \\
21.80 \\
19.00 \\
16.40 \\
\varnothing\end{array}$ & $\begin{array}{l}24.50 \\
\% \% \\
21.00 \\
23.50 \\
36.00 \\
50.00 \\
\%\end{array}$ & $\begin{array}{l}1.3568 \\
\% \\
\varnothing \\
\varnothing \\
\%\end{array}$ & & & \\
\hline
\end{tabular}

$\varnothing$ Test carried out, result negative.

$\%$ Due to lack of substance test not carried out.

of the cells, a phenomenon, already described earlier $(2,6)$, and can be precipitated and enriched by the action of ampholine. This we have mainly observed with the fractions obtained with subtilisin and $\alpha$-chymotrypsin, whereas the amount of phosphorus released by these enzymes is obviously lower as compared with the papain and trypsin samples.

The importance of our findings is not restricted to nucleated red cells, because other authors (9) have also described ribonuclease susceptible charged groups at the surface of Ehrlich ascites tumor cells. Accordingly, future studies will attempt to confirm the concept, that ribonucleic acid must be regarded as a structural component of the cell periphery. However it is yet unknown, by what mechanism nucleic acid material can be partly removed from the cell surface by proteases, which themselves do not contain any phosphorus. Two possibilities offer themselves: the nucleic acid material is more or less loosely associated with the outer glycoprotein coat of the cell and is set free by releasing this coat. The other probability would be, that after the action of proteases a leakage of chicken red cell nucleic acid through the membrane could be possible. Further experiments will deal with the characterisation of the phosphorus-containing fraction by other methods, and will be reported in a second communication on this subject.

\section{Acknowledgement}

The work was supported by Deutsche Forschungsgemeinschaft (SFB 68/IV). We thank Mrs. INGRID M. ZuIDEMa for her excellent technical assistance.

\section{References}

1. Wintzer, G. and G. UhLENBruck, Hoppe-Seyler's Z. physiol. Chem. 351, 834 (1970). - 2. Wintzer, G., G. UhIENBRucK and R. VoigtmanN, Vox sang., in press. - 3. RoElcke, D. and G. UHLENBRUCK, Z. Med. Mikrobiol. Immunol. 155, 156 (1969). 4. KLENK, E. and G. UhLENBruck, Hoppe-Seyler's Z. physiol. Chem. 319, 151 (1960): - 5. Teorell, T., Biochem. Z. 230, 1 (1931). - 6. Seaman, G. V. F. and G. Uhlenbruck, Z. Arztl.
Fortb. (Jena) 14, 739 (1962). - 7. ENGELFRIET, C. P., M. VAN DER HART and J. J. VAN LOGHEM, Vox sang, 4, 445 (1959). 8. SeAman, G. V. F. and G. UhLENBRUCK, Biochim. biophysica Acta, Amsterdam 64, 570 (1962), Arch. Biochem. Biophysics 100, 493 (1963). - 9. Wẹss, L. and E. MArHew, Int. J. Cancer 4, 626 (1969).
Prof. Dr. G. Uhlenbruck Abteil. Immunbiologie 5 Köln 41

Kerpenerstr. 15 